\title{
PENGARUH GREEN PRODUCT KNOWLEDGE, GREEN TRUST DAN PERCEIVED PRICE TERHADAP GREEN PURCHASE INTENTION KONSUMEN AMDK MEREK AQUA DENGAN BOTOL $100 \%$ RECYCLED
}

\author{
Agung Wiranto Setyabudi ${ }^{1}$, Tania Adialita ${ }^{2}$ \\ ${ }^{1}$ Manajemen / Universitas Jenderal Achmad Yani, Jawa Barat \\ ${ }^{2}$ Manajemen / Universitas Jenderal Achmad Yani, Jawa Barat \\ 1agungwiranto@gmail.com \\ ${ }^{2}$ tania.adialita@lecture.unjani.ac.id
}

\begin{abstract}
ABSTRAK
Penelitian ini menguji pengaruh green product knowledge terhadap green purchase intention yang dimediasi oleh green trust dan peran perceived price sebagai moderasi antara green trust dengan green purchase intention pada AMDK merek Aqua dengan botol $100 \%$ recycled. Data yang digunakan dalam penelitian ini adalah data primer yang dikumpulkan dengan strategi survei melalui kuesioner elektronik dengan keterlibatan peneliti rendah, horizon waktu yang digunakan dalam penelitian ini merupakan cross sectional dengan jumlah responden sebanyak 72 orang yang berdomisili di Bali, Bandung dan Jakarta dimana sebanyak 70\% dari responden berusia 17-24 tahun. Penelitian ini menggunakan uji hipotesis dengan software statistic program of social science (SPSS) versi 22. Hasil penelitian ini menunjukkan bahwa green product knowledge berpengaruh positif terhadap green trust, sedangkan green product knowledge tidak berpengaruh terhadap green purchase intention tanpa dimediasi oleh green trust. Hal lainnya ditemukan bahwa green trust berpengaruh positif terhadap green purchase intention dan dapat dimoderasi positif oleh perceived price. Dari hasil penelitian ini, untuk mendorong intensi membeli konsumen pada AMDK merek Aqua dengan botol 100\% recycled, pelaku bisnis perlu menumbuhkan kepercayaan konsumen akan manfaat lebih yang ditawarkan Aqua dengan kemasan barunya untuk lingkungan dan untuk menumbuhkan kepercayaan tersebut pelaku usaha perlu memberikan pengetahuan yang dibutuhkan untuk dapat meyakinkan konsumen.
\end{abstract}

Kata Kunci: Green Product Knowledge, Green Trust, Perceived Price, Green Purchase Intention.

\section{ABSTRACT}

This study examines the effect of green product knowledge on green purchase intention mediated by green trust and the role of perceived price as moderation between green trust and green purchase intention on Aqua brand bottled water with $100 \%$ recycled bottles. The data used in this study are primary data collected through survey strategies through electronic questionnaires with low researcher involvement, the time horizon used in this study is cross-sectional, the number of respondents in this study as many as 72 people from Bali, Bandung, and Jakarta. $70 \%$ of them are age $17-24$ years old. This study uses a hypothesis test with a statistical software program of social science (SPSS) version 22. The results of this study indicate that green product knowledge has a positive effect on green trust. At the same time, green product knowledge does not affect green purchase intention but must be mediated by green trust. The green trust has a positive effect on green intention and can be positively moderated by the perceived price. From the results of this study, to encourage consumer's purchase intentions of Aqua with 100\% recycled bottles, the company needs to foster consumer trust in the added value of new packaging for the environment. To foster this trust, business actors need to provide sufficient knowledge needed to convince consumers.

Keyword: Green Product Knowledge, Green Trust, Perceived Price, Green Purchase Intention.

\section{PENDAHULUAN}

Kondisi lingkungan yang semakin tidak bersahabat membuat masyarakat kian sadar akan pentingnya kepedulian terhadap lingkungan dan mempunyai tanggung jawab besar dalam upaya pelestarian lingkungan (Chen \& Chang, 2012), dimulai dari kesadaran konsumen akan hak-hak mereka untuk membeli produk yang layak dan aman terhadap lingkungan (Fernandes, Astuti, Solimun, Nurjannah, \& Isaskar, 2019). Tetapi pada tahun 2017 konsumsi terhadap sustainable product secara global baru mencapai $22.3 \%$ (Nielsen, 2018)meskipun 63\% konsumen Indonesia mengaku bersedia mengkonsumsi produk ramah lingkungan (WWF Indonesia, 2017).

Pada tahun 2019, Danone Indonesia menawarkan produk Air Minum Dalam Kemasan (AMDK) merek Aqua yang menggunakan 100\% hasil daur ulang di Bali dengan penggunaan 12.000 ton botol plastik per tahun (Rahma, 2019). Peneliti tertarik untuk meneliti minat beli pada green product yang diciptakan Aqua dengan kondisi masih rendahnya pembelian sustainable product di Indonesia. Apakah produk AMDK dengan botol plastik daur ulang ini mampu mendorong minat beli konsumen?

Untuk meningkatkan minat beli AMDK merek Aqua dengan botol $100 \%$ recycled, konsumen perlu mengetahui tentang produk ramah lingkungan sehingga konsumen makin percaya dan bersedia untuk menggunakan produk ramah lingkungan (Wang, Ma, \& Bai, 2018). Kepercayaan konsumen terhadap produk ramah lingkungan atau green trust dihasilkan dari kredibilitas produk ramah lingkungan, kemampuan produk ramah lingkungan, dan dampak terhadap lingkungan (Chen \& Chang, 2012). Dengan membangun green trust yang kuat pada produk ramah lingkungan maka green purchase intention konsumen akan meningkat (Pradnyadewi \& Warmika, 2019). 
Selain green trust, penelitian ini dilakukan pula dengan maksud untuk memperoleh data dan informasi yang berkaitan dengan pengaruh green product knowledge, green trust dan perceived price terhadap green purchase intention pada AMDK merek Aqua dengan botol 100\% recycled. Lalu, hasil penelitian ini juga diharapkan menjadi referensi yang dapat digunakan untuk merumuskan strategi pemasaran dalam rangka menumbuhkan green purchase intention bagi perusahaan Danone dalam mengembangkan AMDK merek Aqua dengan botol $100 \%$ recycled maupun perusahaan sejenis yang ingin mengembangkan kemasannya menjadi kemasan ramah lingkungan dengan memberikan pengetahuan, kepercayaan dan membentuk persepsi akan harga green (sustainable) product.

Mengacu pada latar belakang dan teori yang telah dikemukakan, maka artikel ini bertujuan untuk fokus membahas pengaruh green product knowledge, green trust dan perceived price terhadap green purchase intention konsumen AMDK merek Aqua dengan botol $100 \%$ recycled.

\section{KAJIAN TEORI}

\section{Green Purchase Intention}

Green purchase intention merupakan kemungkinan dan kemauan konsumen yang tertarik pada masalah ramah lingkungan dan sadar untuk memilih produk yang lebih ramah lingkungan dibandingkan dengan produk konvensional dalam proses produksi cenderung memberikan dampak dan pengaruh buruk terhadap lingkungan (Ali \& Ahmad, 2012). Green purchase intention mengacu kepada kesediaan konsumen untuk membeli green product yang memiliki motif akan kekhawatiran kualitas ekologi dan konsekuensi yang ditimbulkan ke lingkungan akibat tindakan pembelian konsumen (Jaiswal \& Kant, 2018). Green purchase intention digambarkan sebagai kemungkinan bahwa seseorang secara khusus memilih produk dengan fitur ramah lingkungan dibandingkan produk tradisional lainnya, dalam pertimbangan pembelian mereka (Rahim, Sulaiman, Chin, Baharun, \& Muharam, 2016). Dalam penelitian ini, green purchase intention adalah kemungkinan konsumen akan membeli produk tertentu yang dihasilkan dari kebutuhan lingkungannya (Chen \& Chang, 2012).

\section{Green Product Knowledge}

Ottman (2011) mendefinisikan green product adalah produk yang biasanya tahan lama, tidak berbahaya bagi kesehatan, pengemasan terbuat dari bahan daur ulang. Produk-produk ini dikenal sebagai ecological atau environmentally friendly, dan sering ditemukan bahwa produk-produk ini melibatkan daur ulang sampai tingkat tertentu, lebih sedikit pengemasan daripada produk tradisional, atau lebih sedikit bahan beracun yang digunakan dalam produksi atau pengemasan sehingga efektif untuk membatasi efek negatif pada lingkungan alami di sekitarnya contohnya termasuk mobil ramah lingkungan (mobil hibrid), produk daur ulang, elektronik hemat energi, teh organik, dan produk perawatan tubuh alami (Al-Gasawneh \& AlAdamat, 2020). Product knowledge merupakan semua pemahaman dan informasi yang dimiliki konsumen mengenai karakteristik produk seperti merek produk, spesifikasi produk, tipe produk, harga produk, dan kelas produk (Sumarwan, 2015). Dalam penelitian ini, green product knowledge mengacu pada pengetahuan subyektif yang merupakan pemahaman konsumen, atribut lingkungan dan dampak lingkungan dari produk hijau (Wang, Ma, \& Bai, 2018).

\section{Green Trust}

Trust adalah keyakinan bahwa kata atau janji pihak lawan dapat diandalkan, dan dia akan memenuhi kewajibannya dalam hubungan pertukaran mereka (Leonidou, Coudounaris, Kvarsova, \& Christodoulides, 2015). Kotler \& Keller (2016) menjelaskan bahwa trust sebagai kesediaan pihak perusahaan untuk mengandalkan mitra bisnis. Kepercayaan bergantung kepada sejumlah faktor interpersonal dan antar organisasi, seperti kompetensi perusahaan, integritas, kejujuran dan kebaikan.

Green trust menurut Lee (2020) yaitu keyakinan atau harapan yang dihasilkan dari kredibilitas, kebajikan, dan kemampuannya mengenai kinerja pro-lingkungan dari produk asing. green trust menunjukkan kesediaan untuk bergantung pada suatu produk, layanan, atau merek berdasarkan pada kepercayaan atau harapan yang dihasilkan dari kredibilitas, kebenaran, dan kemampuan tentang kinerja lingkungannya (Chen \& Weng, 2015). Menurut Akbar et al. (2014) green trust adalah salah satu variabel penentu bagi konsumen dalam peningkatan green purchase intention konsumen. Tingkat green purchase intention yang tinggi disebabkan konsumen memiliki kepercayaan yang baik dengan produsen.

\section{Perceived Price}

Price merupakan sejumlah nilai yang ditukarkan konsumen dengan manfaat dari memiliki atau menggunakan produk atau jasa yang nilainya ditetapkan oleh pembeli dan penjual melalui tawar menawar, atau ditetapkan oleh penjual untuk satu harga yang sama terhadap semua pembeli (Kotler \& Armstrong, Principle Of Marketing, 2014). Sedangkan persepsi atau perceived menurut Schiffman \& Kanuk (2015) merupakan suatu proses seseorang individu dalam menyeleksi, mengorganisasikan, dan menerjemahkan stimulus informasi yang datang menjadi suatu gambaran yang menyeluruh. Perceived menurut Kotler \& Keller (2016) tidak hanya bergantung pada rangsangan fisik tapi juga rangsangan yang 
berhubungan dengan lingkungan sekitar dan keadaan individu yang bersangkutan salah satunya adalah harga. Persepsi konsumen ketika melihat harga sebagai harga yang tinggi, rendah dan atau adil disebut perceived price (Schiffman \& Kanuk, 2015). Perceived price adalah penilaian subyektif pelanggan tentang kewajaran harga untuk suatu produk atau layanan dibandingkan dengan harga referensi pesaing (Zietsman, Mostert, \& Svensson, 2018). Pada penelitian ini, pengertian perceived price mengacu menurut Zietsman et al. (2018).

Konsumen yang lebih tahu tentang produk ramah lingkungan memiliki kepercayaan lebih besar mengenai atribut perlindungan lingkungan dan efek produk ramah lingkungan (Wang, Ma, \& Bai, 2018). Dengan kata lain, semakin banyak pengetahuan yang dimiliki konsumen tentang produk ramah lingkungan, semakin besar kepercayaan mereka pada fungsi dan atribut produk (Wang, Ma, \& Bai, 2018). Studi sebelumnya, menunjukkan bahwa green product knowledge berpengaruh signifikan positif terhadap green trust (Wang, Ma, \& Bai, 2018). Berdasarkan literatur tersebut, hipotesis pertama dalam penelitian ini adalah sebagai berikut:

H1: Green product knowledge berpengaruh positif dan signifikan terhadap green trust

Ketika semakin baik pengetahuan konsumen tentang produk ramah lingkungan, maka niat beli produk ramah lingkungan meningkat, dan sebaliknya jika pengetahuan tentang produk samakin buruk atau negatif, maka niat beli produk ramah lingkungan akan menurun (Indrawati \& Suparna, 2015). Literatur sebelumnya menunjukkan bahwa green product knowledge berpengaruh signifikan positif terhadap green purchase intention (Wu, Hu, Qi, Marinova, \& Shi, 2018). Berdasarkan literatur tersebut, hipotesis kedua dalam penelitian ini adalah sebagai berikut:

H2: Green product knowledge berpengaruh positif dan signifikan terhadap green purchase intention

Penelitian sebelumnya menunjukkan bahwa kepercayaan pelanggan memiliki dampak positif pada niat pembelian pelanggan (Liao, Chung, \& Chang, 2019). Green purchase intention mengacu pada kesediaan konsumen untuk membeli produk ramah lingkungan (Shen, Wang, Lo, \& Shum, 2012). Konuk et al., (2015) menunjukkan bahwa green trust dapat secara positif mempengaruhi green purchase intention. Hal tersebut mengartikan dalam ruang lingkup green consumption, green trust dapat memperkuat green purchase intention konsumen. Demikian pula, Chen \& Chang (2012), Wang et al., (2018) menunjukkan bahwa green trust dapat secara signifikan mempengaruhi green purchase intention. Berdasarkan literatur tersebut, hipotesis ketiga dalam penelitian ini adalah sebagai berikut:

H3: Green trust berpengaruh positif dan signifikan terhadap green purchase intention

Konsumen yang banyak mengetahui tentang produk ramah lingkungan sehingga akan memiliki kepercayaan yang lebih besar mengenai atribut perlindungan lingkungan dan efek dari produk ramah lingkungan, hal tersebut meningkatkan kepercayaan konsumen terhadap produk ramah lingkungan, serta memungkinkan terjadinya pembelian (Wang, Ma, \& Bai, 2018). Green trust dapat memediasi green product knowledge terhadap green purchase intention (Wang, Ma, \& Bai, 2018). Berdasarkan literatur tersebut, hipotesis keempat dalam penelitian ini adalah sebagai berikut:

H4: Green trust memediasi pengaruh green product knowledge terhadap green purchase intention

Ketika harga relatif murah konsumen mempertanyakan kualitas dari produk (Indrawati \& Suparna, 2015), jika harga yang jauh lebih tinggi dari ekspektasi konsumen, konsumen memilih untuk tidak membeli (Barber, Bishop, \& Gruen, 2014) (Steg, Perlaviciute, Van Der Werff, \& Lurvink, 2014). Tetapi harga yang tinggi pada green product menunjukkan produknya berkualitas tinggi dan memiliki fungsi dan efek lingkungan yang dipercaya sehingga konsumen bersedia membayar lebih untuk membeli produk ramah lingkungan (Wang, Ma, \& Bai, 2018). Literatur menunjukkan bahwa perceived price secara positif memoderasi hubungan antara green trust dan green purchase intention (Wang, Ma, \& Bai, 2018). Berdasarkan literatur tersebut, hipotesis kelima dalam penelitian ini adalah sebagai berikut:

H5: $\quad$ Perceived price secara positif memoderasi pengaruh green trust terhadap green purchase intention

Adapun kerangka pemikiran sebagai

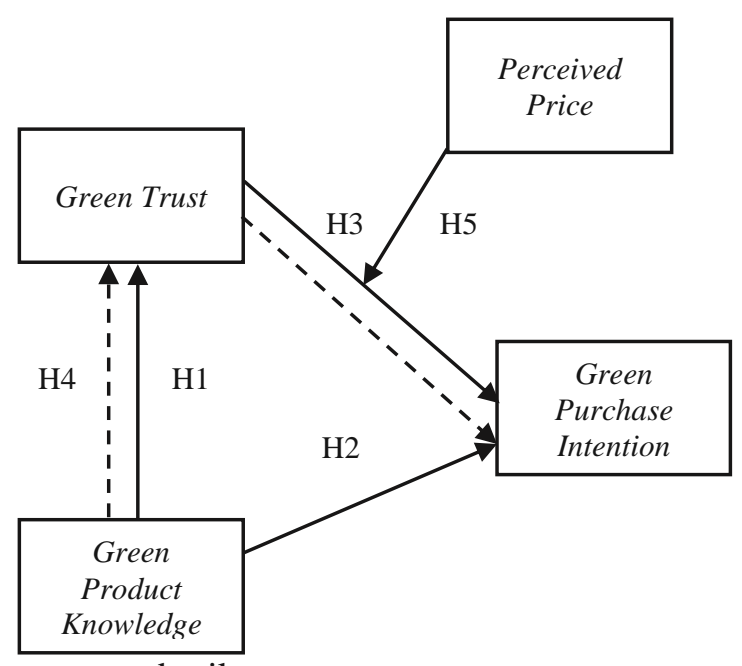

berikut:

Gambar 1. Kerangka Pemikiran 


\section{METODOLOGI}

Penelitian ini termasuk dalam penelitian kuantitatif dengan pendekatan deskriptif dan termasuk studi kausal. Strategi survei dipilih menjadi jenis strategi dalam penelitian ini. Unit analisis pada penelitian ini adalah individual karena jawaban responden akan mewakili pendapatnya sendiri, dan responden penelitian ini adalah pelanggan AMDK merek Aqua dengan usia di atas 17 tahun dengan horizon waktu cross sectional.

Data dikumpulkan melalui instrumen berupa kuesioner dengan desain pengambilan sampel purposive sampling. Untuk pengumpulan data kuesioner digunakan online questionnaires, untuk menyediakan akses ke kelompok atau individu yang sulit ditemui dan tidak mungkin dijangkau melalui saluran lain, serta dianggap sebagai cara yang mudah dan cepat dalam mendapatkan pemahaman lebih mendalam mengenai opini konsumen (Sekaran \& Bougie, 2017) dan meminimalisasi penggunaan kertas. Responden yang difokuskan pada penelitian ini adalah yang bertempat tinggal di Kota Bandung, Jakarta dan Bali karena produk AMDK merek Aqua $100 \%$ recycled tersedia di Jakarta dan Bali (sehataqua.co.id, 2020). Selain itu Danone-Aqua melakukan event di Trans Studio Mall Bandung dalam rangka memperkenalkan produk Aqua Life botol 100\% Recycled (sehataqua.co.id., 2020).

Pada penelitian ini terdapat 5 hipotesis yang diuji. Hipotesis pertama menguji pengaruh dari green product knowledge terhadap green purchase intention menggunakan regresi sederhana.

$$
\mathrm{GT}=\mathrm{a}+\mathrm{b}_{1} \mathrm{GPK}
$$

Selanjutnya regresi berganda digunakan dalam hipotesis kedua dan ketiga pengaruh dari green trust dan green product knowledge terhadap green purchase intention.

$$
\mathrm{GPI}=\mathrm{a}+\mathrm{b}_{2} \mathrm{GPK}+\mathrm{b}_{3} \mathrm{GT}
$$

Dalam hipotesis keempat akan diuji pengaruh dari green product knowledge terhadap green purchase intention dimediasi oleh green trust digunakan sobel test. Uji sobel dilakukan melalui kalkulator uji Sobel online dari Preacher \& Leonardelli (2020), sementara pengolahan data yang digunakan untuk analisis regresi yaitu menggabungkan statistic program of social science (SPSS) versi 22. Hipotesis kelima menguji pengaruh dari green trust terhadap green purchase intention yang dimoderasi oleh perceived price menggunakan Moderated Regression Analysis (MRA). Secara formulatif persamaan regresi berganda dinyatakan dalam persamaan (3) sebagai berikut:

$$
\mathrm{GPI}=\mathrm{a}+\mathrm{b}_{4} \mathrm{GPK}+\mathrm{b}_{5} \mathrm{GT}+\mathrm{b}_{6} \mathrm{PP}+\mathrm{b}_{7} \mathrm{GTxPP}
$$

Uji asumsi klasik dilakukan untuk memenuhi syarat analisis regresi linier, yaitu Best Linear Unbiased Estimate (BLUE). Beberapa asumsi yang harus terpenuhi agar kesimpulan dari hasil pengujian tidak bias diantaranya adalah uji normalitas, uji multikolinieritas (untuk regresi berganda), uji heteroskedastisitas dan uji autokorelasi (Ghozali, 2016). Dalam penelitian ini, teknik pengolahan data munggunakan statistic program of social science (SPSS) versi 22.

\section{Operasional Variabel}

Pada penelitian ini terdapat 4 variabel yang akan diteliti. Green product knowledge (GPK) sebagai variabel independen, green trust (GT) adalah variabel independen, dependen dan intervening, green purchase intention (GPI) adalah variabel dependen, serta perceived price $(\mathrm{PP})$ adalah

\begin{tabular}{|c|c|c|c|}
\hline $\begin{array}{l}\text { VARI } \\
\text { ABEL }\end{array}$ & $\begin{array}{c}\text { DEFINISI } \\
\text { VARIABEL }\end{array}$ & INDIKATOR & SUMBER \\
\hline $\begin{array}{l}\text { Green } \\
\text { Produ } \\
\text { ct } \\
\text { knowl } \\
\text { edge } \\
\text { (GPK) }\end{array}$ & $\begin{array}{l}\text { Pengetahuan } \\
\text { subjektif dari } \\
\text { pemahaman } \\
\text { konsumen akan } \\
\text { atribut } \\
\text { lingkungan dan } \\
\text { dampak } \\
\text { lingkungan } \\
\text { dari produk } \\
\text { ramah } \\
\text { lingkungan } \\
\text { (Wang, Ma, \& } \\
\text { Bai, 2018) }\end{array}$ & $\begin{array}{l}\text { - Pemahaman } \\
\text { Label } \\
\text { information } \\
\text { - Pemahaman } \\
\text { certification } \\
\text { organization } \\
\\
\text { - Pemahaman } \\
\text { akan } \\
\text { Environmental } \\
\text { impact of the } \\
\text { products } \\
\text { - Pemahaman } \\
\text { akan } \\
\text { perubahaan } \\
\text { nyata terhadap } \\
\text { lingkungan }\end{array}$ & $\begin{array}{l}\text { (Chen \& } \\
\text { Deng, 2015) } \\
\\
\text { (Leonidou, } \\
\text { Coudounaris, } \\
\text { Kvarsova, \& } \\
\text { Christodoulid } \\
\text { es, 2015) }\end{array}$ \\
\hline $\begin{array}{l}\text { Green } \\
\text { Trust } \\
\text { (GT) }\end{array}$ & $\begin{array}{l}\text { Kesediaan } \\
\text { untuk } \\
\text { bergantung } \\
\text { pada suatu } \\
\text { produk, } \\
\text { layanan, atau } \\
\text { merek } \\
\text { berdasarkan } \\
\text { pada } \\
\text { kepercayaan } \\
\text { atau harapan } \\
\text { yang } \\
\text { dihasilkan dari } \\
\text { kredibilitas, } \\
\text { kebenaran, dan } \\
\text { kemampuan } \\
\text { tentang kinerja } \\
\text { lingkungannya } \\
\text { (Chen, Lin, \& } \\
\text { Weng, 2015) }\end{array}$ & $\begin{array}{l}\text { - Kepercayaan } \\
\text { akan } \\
\text { Environmental } \\
\text { image } \\
\text { - Kepercayaan } \\
\text { akan } \\
\text { Environmental } \\
\text { functionality } \\
\text { - Kepercayaan } \\
\text { akan } \\
\text { Environmental } \\
\text { claims } \\
\text { - Kepercayaan } \\
\text { akan } \\
\text { Environmental } \\
\text { performance }\end{array}$ & $\begin{array}{l}\text { (Chen \& } \\
\text { Weng, 2015) }\end{array}$ \\
\hline $\begin{array}{l}\text { Percei } \\
\text { ved } \\
\text { Price } \\
\text { (PP) }\end{array}$ & $\begin{array}{l}\text { Sebagai } \\
\text { penilaian } \\
\text { subyektif } \\
\text { pelanggan } \\
\text { tentang } \\
\text { kewajaran }\end{array}$ & $\begin{array}{l}\text { Perbandingan } \\
\text { harga green } \\
\text { product } \\
\text { dengan } \\
\text { conventional } \\
\text { product }\end{array}$ & $\begin{array}{l}\text { (He \& Zhan, } \\
2018)\end{array}$ \\
\hline
\end{tabular}
variabel moderator.

Tabel 1. Operasional Variabel 


\begin{tabular}{|c|c|c|c|}
\hline & $\begin{array}{l}\text { harga untuk } \\
\text { suatu produk } \\
\text { atau layanan } \\
\text { dibandingkan } \\
\text { dengan harga } \\
\text { referensi } \\
\text { pesaing } \\
\text { (Zietsman et } \\
\text { al., 2018) }\end{array}$ & $\begin{array}{l}\text { - Perbandingan } \\
\text { harga green } \\
\text { product } \\
\text { dengan } \\
\text { ekspetasi } \\
\text { - Expensive } \\
\text { price } \\
\text { - Costly price. }\end{array}$ & \\
\hline $\begin{array}{l}\text { Green } \\
\text { Purch } \\
\text { ase } \\
\text { Intenti } \\
\text { on } \\
\text { (GPI) }\end{array}$ & $\begin{array}{l}\text { Kemungkinan } \\
\text { konsumen akan } \\
\text { membeli } \\
\text { produk tertentu } \\
\text { yang } \\
\text { dihasilkan dari } \\
\text { kebutuhan } \\
\text { lingkungannya } \\
\text { (Chen \& } \\
\text { Chang, 2012) }\end{array}$ & $\begin{array}{l}\text { - Kesediaan } \\
\text { memilih green } \\
\text { product } \\
\text { dibandingkan } \\
\text { conventional } \\
\text { product } \\
\text { - Pembelian } \\
\text { green products } \\
\text { di masa depan } \\
\\
\text { - Pemberian } \\
\text { rekomendasi } \\
\text { green products } \\
\text { kepada orang- } \\
\text { orang di } \\
\text { sekeliling } \\
\text { konsumen }\end{array}$ & (Lee, 2017) \\
\hline
\end{tabular}

Variabel yang digunakan dalam penelitian ini diturunkan kedalam indikator (Tabel 1). Kemudian indikator-indikator tersebut dijadikan sebagai tolak ukur dengan mengembangkan indikator tersebut menjadi pernyataan-pernyataan yang dituangkan ke dalam kuesioner berdasarkan teori terdahulu.

\section{PEMBAHASAN DAN HASIL PENELITIAN}

\section{Hasil Penelitian}

Hasil penelitian ini melibatkan 72 responden yang berdomisili di Kota Bandung, Jakarta dan Bali yang telah mengetahui produk AMDK merek Aqua dengan botol $100 \%$ recycled dengan usia di atas 17 tahun. Responden dibagi berdasarkan domisili, usia, pendidikan dan pekerjaan. Hasil berdasarkan domisili sebanyak 40 orang domisili Bandung, 30 orang domisili Jakarta dan sisanya domisili Bali. Hasil berdasarkan usia sebanyak 53 dengan usia 17-24 tahun, 18 dengan usia 25-34 tahun, dan sisanya usia diatas 45 tahun. Lalu berdasarkan pendidikan yang paling banyak pendidikan S-1/D-IV sebanyak 44 orang, diikuti pendidikan SMA sederajat sebanyak 19 orang. Hasil berdasarkan pekerjaan merupakan mahasiswa sebanyak 40 orang, lalu karyawan 11 orang, dan sebanyak 21 orang terdiri dari swasta, pegawai negeri, wirausaha, dokter, ibu rumah tangga, dan belum bekerja. Berdasarkan penghasilan sebanyak 57 orang berpenghasilan di bawah 4.5 juta rupiah dan sisanya di atas 4.5 juta rupiah.

Penelitian ini berhasil melibatkan 72 responden yang berdomisili di Kota Bandung, Jakarta dan Bali yang telah mengetahui produk AMDK merek Aqua dengan botol $100 \%$ recycled dengan usia di atas 17 tahun. Usia ini dipertimbangkan sebagai acuan usia responden yang sudah dianggap dewasa untuk dapat menjawab pertanyaan pada kuesioner dengan baik.

Hasil rata-rata jawaban responden tiap variabel dari green product knowledge, green trust, perceived price dan green purchase intention dengan masing-masing jumlah pernyataan 4, 4, 4, dan 3 sebesar 3.92, 3.5, 3.84 dan 3.89.

\begin{tabular}{|c|c|c|}
\hline KODE & $\begin{array}{c}\text { HASIL UJI } \\
\text { VALIDITAS }\end{array}$ & $\begin{array}{c}\text { HASIL UJI } \\
\text { RELIABILITAS }\end{array}$ \\
\hline \multicolumn{3}{|c|}{ Green Product Knowledge } \\
\hline GPK1 & 0.705 & \multirow{4}{*}{0.769} \\
\hline GPK 2 & 0.720 & \\
\hline GPK 3 & 0.839 & \\
\hline GPK 4 & 0.806 & \\
\hline \multicolumn{3}{|c|}{ Green Trust } \\
\hline GT1 & 0.822 & \multirow{4}{*}{0.785} \\
\hline GT2 & 0.778 & \\
\hline GT3 & 0.723 & \\
\hline GT4 & 0.809 & \\
\hline \multicolumn{3}{|c|}{ Perceived Price } \\
\hline PP1 & 0.818 & \multirow{4}{*}{0.919} \\
\hline PP2 & 0.911 & \\
\hline PP3 & 0.940 & \\
\hline PP4 & 0.922 & \\
\hline \multicolumn{3}{|c|}{ Green Purchase Intention } \\
\hline GPI1 & 0.898 & \multirow{3}{*}{0.868} \\
\hline GPI2 & 0.893 & \\
\hline GPI3 & 0.898 & \\
\hline
\end{tabular}

Hasil uji validitas dan reliabilitas pada penelitian ini dalam tabel 2 dengan kriteria uji validitas yaitu jika $r_{\text {hitung }}>r_{\text {tabel }}$ maka data tersebut dinyatakan valid. Dimana $r_{\text {tabel }}$ sebesar 0,2787 sehingga pengujian instrumen penelitian ini dinyatakan semua valid karena setiap instrumen $\mathrm{r}_{\text {hitung }}$ lebih besar daripada 0,2787. Lalu kriteria uji reliabilitas yaitu jika nilai cronbach alpha diatas 0,60 dapat diterima, sehingga pernyataan pada variabel GPK, GT, PP dan GPI dapat diterima karena nilai cronbach alpha diatas 0,60 .

\section{Hasil Uji Asumsi Klasik}

a. Uji Normalitas

Hasil uji normalitas data berdasarkan persamaan satu, dua, dan tiga menunjukkan angka signifikansi (sig.) sebesar 0,200>0,05 yang mengindikasikan bahwa data pada penelitian ini berdistribusi normal. Hasil uji normalitas dapat dilihat pada tabel 3 di bawah ini. 
Tabel 3. Hasil Uji Normalitas

One-Sample Kolmogorov-Smirnov Test

\begin{tabular}{|c|c|c|c|c|}
\hline & \multicolumn{3}{|c|}{ Unstandardized Residual } \\
\hline & & (1) & (2) & (3) \\
\hline \multicolumn{2}{|l|}{$\mathbf{N}$} & 72 & 72 & 72 \\
\hline Normal & Mean & .0000000 & .0000000 & .0000000 \\
\hline Parameter & Std. & & & \\
\hline & $\begin{array}{l}\text { Deviati } \\
\text { on }\end{array}$ & 2.00655719 & 1.96201356 & 1.77480031 \\
\hline $\begin{array}{l}\text { Most } \\
\text { Extreme }\end{array}$ & $\begin{array}{l}\text { Absolu } \\
\text { te }\end{array}$ & .080 & .078 & .083 \\
\hline $\begin{array}{l}\text { Difference } \\
\mathrm{s}\end{array}$ & $\begin{array}{l}\text { Positiv } \\
\text { e }\end{array}$ & .063 & .048 & .060 \\
\hline & $\begin{array}{l}\text { Negati } \\
\text { ve }\end{array}$ & -.080 & -.078 & -.083 \\
\hline \multirow{2}{*}{\multicolumn{2}{|c|}{$\begin{array}{l}\text { Test Statistic } \\
\text { Asymp. Sig. (2- } \\
\text { tailed) }\end{array}$}} & .080 & .078 & .083 \\
\hline & & $.200^{\mathrm{c}, \mathrm{d}}$ & $.200^{\mathrm{c}, \mathrm{d}}$ & $.200^{\mathrm{c}, \mathrm{d}}$ \\
\hline
\end{tabular}

a. Test distribution is Normal.

b. Calculated from data.

c. Lilliefors Significance Correction.

d. This is a lower bound of the true significance.

b. Uji Multikolinearitas

Uji multikolinearitas tidak lakukan pada model regresi persamaan (1) karena persamaan (1) merupakan model regresi sederhana dan persamaan (3) merupakan model regresi moderasi. Ghozali, (2016) menyatakan uji multikolinieritas pada regresi dengan Moderated Regression Analysis (MRA) pada umumnya menimbulkan masalah oleh karena akan terjadi multikolinieritas yang tinggi antara variabel independen.

Tabel 4. Hasil Uji Multikolinearitas Persamaan (2) Coefficients

\begin{tabular}{|c|c|c|c|}
\hline \multirow{2}{*}{\multicolumn{2}{|c|}{ Model }} & \multicolumn{2}{|c|}{\begin{tabular}{|l|} 
Collinearity Statistics \\
\end{tabular}} \\
\hline & & Tolerance & VIF \\
\hline \multirow{3}{*}{\multicolumn{2}{|c|}{$\begin{array}{ll} & \text { (Constant) } \\
2 & \text { GT } \\
& \text { GPK }\end{array}$}} & & \\
\hline & & .720 & 1.389 \\
\hline & & .720 & 1.389 \\
\hline
\end{tabular}

a. Dependent Variable: GPI

Berdasarkan hasil uji multikolinearitas pada tabel 4, dapat diketahui bahwa variabel gren trust dan green product knowledge memiliki nilai toleransi 0.720 lebih besar dari 0.10 dan nilai VIF sebesar 1.389 lebih kecil dari 10. Dengan demikian maka tidak terjadi multikolinearitas. Artinya dua atau lebih variabel bebas dalam model regresi tidak saling berkorelasi.

c. Uji Heteroskedastisitas

Tabel 5. Hasil Uji Heteroskedastisitas

\begin{tabular}{|c|c|c|}
\hline \multicolumn{3}{|c|}{ Coefficients $^{\mathrm{a}}$} \\
\hline Model & $\mathbf{t}$ & Sig. \\
\hline \multirow{2}{*}{$\mathbf{1} \begin{array}{l}\text { (Constant) } \\
\text { GPK }\end{array}$} & 2.769 & .007 \\
\hline & -1.298 & .198 \\
\hline \multicolumn{3}{|c|}{ a. Dependent Variable: Abs_Res1 } \\
\hline Model & $\mathbf{t}$ & Sig. \\
\hline (Constant) & 2.399 & .019 \\
\hline 2 GPK & -.953 & .344 \\
\hline GT & .143 & .887 \\
\hline \multicolumn{3}{|c|}{ a. Dependent Variable: Abs_Res2 } \\
\hline Model & $\mathbf{t}$ & Sig. \\
\hline
\end{tabular}

\begin{tabular}{|c|c|c|c|}
\hline \multicolumn{4}{|c|}{ 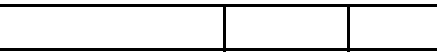 } \\
\hline & (Constant) & .276 & .783 \\
\hline & GPK & -.194 & .847 \\
\hline 3 & GT & .282 & .779 \\
\hline & PP & 1.854 & .068 \\
\hline & GTxPP & -1.722 & .090 \\
\hline
\end{tabular}

Hasil uji heteroskedastisitas pada tabel 5 menunjukkan setiap variabel di persamaan (1), (2), dan (3) menunjukkan angka signifikansi lebih besar daripada 0.05 maka terbebas dari heteroskedastisitas atau tidak terjadi heteroskedastisitas

\section{Hasil Uji Regresi}

a. Hasil Uji Regresi Persamaan (1)

Hasil uji regresi persamaan pertama merupakan analisis regresi linier sederhana untuk menjawab hipotesis pertama mengenai pengaruh dari green product knowledge terhadap green trust. Hasil uji regresi persamaan pertama ditunjukkan tabel 6 berikut ini :

Tabel 6. Hasil Uji Regresi Persamaan (1)

\begin{tabular}{|c|c|c|c|c|c|}
\hline \multicolumn{7}{|c|}{ Coefficients } \\
\hline \multirow{2}{*}{ Model } & \multicolumn{2}{|c|}{$\begin{array}{c}\text { Unstandardized } \\
\text { Coefficients }\end{array}$} & $\begin{array}{c}\text { Standardiz } \\
\text { ed } \\
\text { Coefficients }\end{array}$ & \multirow{2}{*}{ t Sig. } \\
\cline { 2 - 5 } & $\mathbf{B}$ & $\begin{array}{c}\text { Std. } \\
\text { Error }\end{array}$ & Beta & & \\
\hline $\begin{array}{l}\text { (Consta } \\
\text { nt) } \\
\text { GPK }\end{array}$ & 6.491 & 1.456 & & 4.457 & .000 \\
\hline
\end{tabular}

a. Dependent Variable: GT

Berdasarkan hasil pengolahan data tersebut, dapat diketahui hasil persamaan regresi sederhana sebagai berikut :

$$
\mathrm{GT}=0.6491+0.478 \mathrm{GPK}
$$

Koefisien determinasi persamaan (1) ditunjukkan oleh tabel 7.

Tabel 7. Koefisien Determinasi Persamaan (1)

\begin{tabular}{|c|c|c|c|c|}
\hline Model & R & $\begin{array}{c}\text { R } \\
\text { Square }\end{array}$ & $\begin{array}{c}\text { Adjusted R } \\
\text { Square }\end{array}$ & $\begin{array}{c}\text { Std. Error of the } \\
\text { Estimate }\end{array}$ \\
\hline 1 & $.529^{\mathrm{a}}$ & .280 & .270 & 2.021 \\
\hline
\end{tabular}

a. Predictors: (Constant), GPK

b. Dependent Variable: GT

b. Hasil Uji Regresi Persamaan (2)

Hasil uji regresi persamaan kedua pada tabel 8 merupakan analisis regresi linier berganda untuk menjawab hipotesis kedua dan ketiga mengenai pengaruh dari green product knowledge dan green trust terhadap green purchase intention. Koefisien determinasi persamaan (2) ditunjukkan oleh tabel 10. 
Tabel 8. Hasil Uji Regresi Persamaan (2) Coefficients

\begin{tabular}{|c|c|c|c|c|c|}
\hline \multirow{2}{*}{ Model } & \multicolumn{2}{|c|}{$\begin{array}{c}\text { Unstandardized } \\
\text { Coefficients }\end{array}$} & $\begin{array}{c}\text { Standardized } \\
\text { Coefficients }\end{array}$ & \multirow{2}{*}{ T } & \multirow{2}{*}{ Sig. } \\
\cline { 2 - 4 } & B & Std. Error & Beta & & \\
\hline (Constant) & 1.427 & 1.625 & & .878 & .383 \\
2 GPK & .174 & .106 & .182 & 1.636 & .106 \\
GT & .537 & .118 & .507 & 4.563 & .000 \\
\hline
\end{tabular}

a. Dependent Variable: GPI

Berdasarkan hasil pengolahan data tersebut, dapat diketahui hasil persamaan regresi berganda sebagai berikut:

$\mathrm{GPI}=1.427+0.174 \mathrm{GPK}+0.537 \mathrm{GT}$

Tabel 9. Hasil Uji F Persamaan (2)

$\mathrm{ANOVA}^{\mathrm{a}}$

\begin{tabular}{|c|c|c|c|c|c|c|}
\hline \multicolumn{7}{|c|}{$\mathrm{ANOVA}^{\mathrm{a}}$} \\
\hline & Model & $\begin{array}{l}\text { Sum of } \\
\text { Squares }\end{array}$ & df & $\begin{array}{c}\text { Mean } \\
\text { Square }\end{array}$ & $\mathbf{F}$ & Sig. \\
\hline \multirow{3}{*}{2} & Regression & 172.686 & 2 & 86.343 & 21.798 & $.000^{\mathrm{b}}$ \\
\hline & Residual & 273.314 & 69 & 3.961 & & \\
\hline & Total & 446.000 & 71 & & & \\
\hline \multicolumn{7}{|c|}{ a. Dependent Variable: GPI } \\
\hline \multicolumn{7}{|c|}{ b. Predictors: (Constant), GT, GPK } \\
\hline
\end{tabular}

Tabel 10. Koefisien Determinasi Persamaan (2)

Model Summary

\begin{tabular}{|c|c|c|c|c|}
\hline Model & $\mathbf{R}$ & $\begin{array}{c}\mathbf{R} \\
\text { Square }\end{array}$ & $\begin{array}{c}\text { Adjusted R } \\
\text { Square }\end{array}$ & $\begin{array}{c}\text { Std. Error of the } \\
\text { Estimate }\end{array}$ \\
\hline $\mathbf{2}$ & $.622^{\mathrm{a}}$ & .387 & .369 & 1.990 \\
\hline
\end{tabular}

a. Predictors: (Constant), GT, GPK

b. Dependent Variable: GPI

c. Hasil Uji Regresi Persamaan (3)

Hasil uji regresi persamaan ketiga pada

tabel 11 merupakan analisis regresi linier moderasi untuk menjawab hipotesis kelima mengenai pengaruh dari green trust terhadap green purchase intention yang dimoderasi oleh perceived price.

Tabel 11. Hasil Uji Regresi Persamaan (3) Coefficients

\begin{tabular}{|l|r|r|c|c|c|}
\hline \multirow{2}{*}{ Model } & \multicolumn{2}{|c|}{$\begin{array}{c}\text { Unstandardized } \\
\text { Coefficients }\end{array}$} & $\begin{array}{c}\text { Standardized } \\
\text { Coefficients }\end{array}$ & \multirow{2}{*}{ T } & \multirow{2}{*}{ Sig. } \\
\cline { 2 - 5 } & B & $\begin{array}{c}\text { Std. } \\
\text { Error }\end{array}$ & Beta & & \\
\hline (Constant) & 5.853 & 3.691 & & 1.586 & .117 \\
GPK & .074 & .107 & .078 & .698 & .488 \\
3 GT & .082 & .233 & .077 & .352 & .726 \\
PP & -.191 & .252 & -.298 & -.760 & .450 \\
GTxPP & .029 & .018 & .851 & 1.648 & .014 \\
\hline
\end{tabular}

Berdasarkan hasil pengolahan data tersebut, dapat diketahui hasil persamaan regresi moderasi sebagai berikut:

$$
\begin{aligned}
\mathrm{GPI}= & 5.853+0.074 \mathrm{GPK}+0.082 \mathrm{GT}-0.191 \mathrm{PP} \\
& +0.029 \mathrm{GT} x \mathrm{PP}
\end{aligned}
$$

Tabel 12. Hasil Uji F Persamaan (3)

$$
\text { ANOVA }^{\mathrm{a}}
$$

\begin{tabular}{|l|l|r|r|r|r|r|}
\hline \multicolumn{2}{|c|}{ Model } & $\begin{array}{l}\text { Sum of } \\
\text { Squares }\end{array}$ & df & $\begin{array}{l}\text { Mean } \\
\text { Square }\end{array}$ & F & Sig. \\
\hline \multirow{3}{*}{3} & Regression & 222.356 & 4 & 55.589 & 16.654 & $.000^{\mathrm{b}}$ \\
\cline { 2 - 7 } & Residual & 223.644 & 67 & 3.338 & & \\
\cline { 2 - 7 } & Total & 446.000 & 71 & & & \\
\hline
\end{tabular}

Tabel 13.Koefisien Determinasi (3)

\begin{tabular}{|c|c|c|c|c|}
\multicolumn{5}{|c|}{ Model Summary } \\
\hline Model & $\mathbf{R}$ & $\begin{array}{c}\text { R } \\
\text { Square }\end{array}$ & $\begin{array}{c}\text { Adjusted R } \\
\text { Square }\end{array}$ & $\begin{array}{c}\text { Std. Error of the } \\
\text { Estimate }\end{array}$ \\
\hline 3 & $.706^{\mathrm{a}}$ & .499 & .469 & 1.827 \\
\hline
\end{tabular}

a. Predictors: (Constant), GTxPP, GT, PP

b. Dependent Variable: GPI

\section{Hasil Uji Sobel}

Uji sobel digunakan untuk menjawab hipotesis keempat mengenai pengaruh dari green product knowledge terhadap green purchase intention dimediasi oleh green trust. Analisis untuk uji sobel dilakukan melalui situs quantpsy.org yang diciptakan Preacher \& Leonardelli (2010). Hasil Uji Sobel ditunjukkan oleh tabel 14 di bawah ini :

\begin{tabular}{|r|l|l|l|}
\multicolumn{2}{c}{ Tabel 14. Hasil Uji Sobel } \\
\hline & Test statistic: & Std.Error: & $p$-value: \\
\hline Sobel test: & 3.42334236 & 0.07498111 & 0.00061856 \\
\hline Aorian test: & 3.38801646 & 0.07576291 & 0.000704 \\
\hline Goodman test: & 3.45979681 & 0.07419106 & 0.00054058 \\
\hline
\end{tabular}

\section{Hasil Uji Hipotesis}

Hasil uji hipotesis pada tabel 15 bertujuan untuk menguji pengaruh green product knowledge terhadap green purchase intention yang dimediasi oleh green trust dan peran perceived price sebagai

\begin{tabular}{|c|c|c|}
\hline \multicolumn{3}{|c|}{$\begin{array}{l}\text { Tabel 15. Hasil Uji Hipotesis } \\
\text { Coefficients }\end{array}$} \\
\hline Model & $\mathbf{T}$ & Sig. \\
\hline \multirow{2}{*}{$\begin{array}{ll}1 & \text { (Constant) } \\
\text { GPK }\end{array}$} & 4.457 & .000 \\
\hline & 5.216 & .000 \\
\hline \multicolumn{3}{|c|}{ a. Dependent Variable: GT } \\
\hline \multirow{3}{*}{$\begin{array}{ll} & \text { (Constant) } \\
2 & \text { GPK } \\
& \text { GT } \\
\end{array}$} & .878 & .383 \\
\hline & 1.636 & .106 \\
\hline & 4.563 & .000 \\
\hline \multicolumn{3}{|c|}{ b. Dependent Variable: GPI } \\
\hline (Constant) & 2.326 & .023 \\
\hline GPK & .698 & .488 \\
\hline 3 GT & .262 & .794 \\
\hline $\mathbf{P P}$ & -1.093 & .278 \\
\hline GTxPP & 2.103 & .039 \\
\hline \multicolumn{3}{|c|}{ c. Dependent Variable: GPI } \\
\hline 4 GPK-GT & 3.423 & .000 \\
\hline
\end{tabular}
moderasi antara green trust dengan green purchase intention.

a. Hipotesis pertama mengenai pengaruh green product knowledge terhadap green trust menunjukkan nilai $t_{\text {hitung }}$ sebesar $5.216>1.66691$ $\left(\mathrm{t}_{\text {tabel }}\right)$ dengan nilai signifikansi $0.000<0.05$. Hal tersebut menandakan bahwa $\mathrm{H}_{0}$ ditolak dan $\mathrm{H}_{\mathrm{a}}$ diterima. Artinya green product knowledge berpengaruh positif dan signifikan terhadap green trust.

b. Hipotesis kedua mengenai pengaruh green product knowledge terhadap green purchase intention menunjukkan nilai $t_{\text {hitung }}$ sebesar 1.636 $<1.66691\left(\mathrm{t}_{\text {tabel }}\right)$ dengan nilai signifikansi 0.106 $<0.05$. Hal tersebut menandakan bahwa $\mathrm{H}_{\mathrm{a}}$ ditolak dan $\mathrm{H}_{0}$ diterima. Artinya green product knowledge tidak berpengaruh terhadap green purchase intention.

c. Hipotesis ketiga mengenai pengaruh green trust terhadap green purchase intention menunjukkan nilai $\mathrm{t}_{\text {hitung }}$ sebesar $4.563>1.66691\left(\mathrm{t}_{\text {tabel }}\right)$ dengan 
nilai signifikansi $0.000<0.05$. Hal tersebut menandakan bahwa $\mathrm{H}_{0}$ ditolak dan $\mathrm{H}_{\mathrm{a}}$ diterima. Artinya green trust berpengaruh positif dan signifikan terhadap green purchase intention.

d. Hipotesis keempat mengenai pengaruh green product knowledge terhadap green purchase intention dimediasi oleh green trust menunjukkan nilai $t_{\text {hitung }}$ sebesar $3.423>1.66724$ $\left(\mathrm{t}_{\text {tabel }}\right)$ dengan nilai signifikansi $0.000<0.05$. Hal tersebut menandakan bahwa $\mathrm{H}_{0}$ ditolak dan $\mathrm{H}_{\mathrm{a}}$ diterima. Artinya green product knowledge berpengaruh positif dan signifikan terhadap green purchase intention dimediasi oleh green trust.

e. Hipotesis kelima mengenai pengaruh green trust terhadap green purchase intention dimoderasi oleh perceived price menunjukkan nilai $t_{\text {hitung }}$ sebesar $2.103>1.66757\left(\mathrm{t}_{\text {tabel }}\right)$ dengan nilai signifikansi $0.039<0.05$. Hal tersebut menandakan bahwa $\mathrm{H}_{0}$ ditolak dan $\mathrm{H}_{\mathrm{a}}$ diterima. Artinya green trust berpengaruh positif dan signifikan terhadap green purchase intention dimoderasi oleh perceived price.

\section{Pembahasan}

Berdasarkan hasil penelitian, sebanyak 53 dari 72 responden yang mengembalikan kuesioner daring berusia 17-24 tahun (Dimock, 2019).

Tabel 16. Skala Kecenderungan Jawaban Responden

\begin{tabular}{|l|c|}
\hline \multicolumn{1}{|c|}{ Kategori } & Skala \\
\hline Sangat Rendah & $1.00-1.80$ \\
\hline Rendah & $1.81-2.60$ \\
\hline Sedang & $2.61-3.40$ \\
\hline Tinggi & $3.41-4.20$ \\
\hline Sangat Tinggi & $4.21-5.00$ \\
\hline
\end{tabular}

Dalam penelitian ini didapatkan skor ratarata jawaban responden untuk variabel green product knowledge sebesar 3.92, lalu green trust sebesar 3.50, perceived price sebesar 3.84 dan green purchase intention sebesar 3.89. Skor tersebut mengacu pada tabel 16 termasuk skor dengan kategori tinggi yang artinya bahwa responden dalam penelitian ini memiliki pengetahuan yang tinggi dari green product, memiliki kepercayaan yang cukup terhadap green product, harga yang dipersepsikan konsumen pada green product tinggi, dan memiliki minat beli terhadap green product yang tinggi. Pada variabel green product knowledge, indikator pemahaman akan environmental impact of the products memiliki skor rata-rata tertinggi (4.04) dan termasuk kategori tinggi yang artinya responden memiliki pengetahuan yang tinggi akan dampak green product bagi lingkungan, lalu pada variabel green trust, perceived price dan green purchase intention skor indikator yang termasuk kategori skor tinggi yaitu kepercayaan akan environmental performance, perbandingan harga green product dengan conventional product, dan minat membeli green products di masa depan yang artinya reponden memiliki kepercayaan yang tinggi dari kinerja lingkungan green product, mereka setuju bahwa harga produk Aqua Life 100\% Recycled lebih mahal dari air mineral lainnya dan memiliki minat yang tinggi untuk membeli green product di masa depan. Sedangkan indikator dengan rata-rata skor terendah dan mengacu kepada tabel 23 termasuk kategori tinggi dari variabel green product knowledge, green trust, perceived price dan green purchase intention yaitu pemahaman responden akan certification organization (GPK2), kepercayaan responden akan environmental claims (GT3), perbandingan harga green product dengan ekspetasi (PP2), dan kesediaan memilih green product dibandingkan conventional product (GPI1).

Selanjutnya, berdasarkan hasil uji hipotesis diketahui bahwa green product knowledge tidak berpengaruh langsung terhadap green purchase intention tetapi green product knowledge dapat berpengaruh positif dan signifikan terhadap green purchase intention jika dimediasi oleh green trust. Artinya, meskipun konsumen memiliki pengetahuan yang baik akan green product, tanpa adanya kepercayaan atau keyakinan akan dampak green product tersebut terhadap lingkungan, minat beli konsumen tidak akan timbul. Temuan penelitian hipotesis kedua yaitu green product knowledge berpengaruh positif dan signifikan terhadap green purchase intention sejalan dengan penelitian (Indrawati \& Suparna, 2015; Kanchanapibul, Lacka, Wang, \& Chan, 2014; Newton, Tsarenko, Ferraro, \& Sands, 2015) dan hipotesis 5 yaitu perceived price secara positif memoderasi pengaruh green trust terhadap green purchase intention sejalan dengan penelitian Wang et al. (2018). Temuan ini juga menjadi jawaban gap yang disebutkan pada latar belakang penelitian ini bahwa 63\% konsumen Indonesia bersedia mengkonsumsi produk ramah lingkungan dengan harga yang lebih tinggi (WWF Indonesia, 2017) tetapi penjualan green (sustainable) products secara global pada tahun 2017 hanya mencapai $22.30 \%$ (Nielsen, 2018). Hal ini terjadi dapat terjadi karena tidak adanya keyakinan akan green product terhadap lingkungan sehingga konsumen ragu atau tidak berminat membeli. Sebaliknya, ketika pemahaman konsumen tentang atribut lingkungan dan dampak lingkungan dari green product tinggi maka kepercayaan mereka akan dampak positif green product terhadap lingkungan akan semakin tinggi. Pada penelitian ini ditemukan sebanyak $46,05 \%$ responden masih belum banyak yang percaya dari dampak positif green product pada lingkungan.

Terkait perceived price, pada penelitian ini $79,2 \%$ responden berusia 17 - 24 tahun dimana responden masih memiliki penghasilan dibawah penghasilan menengah sehingga mereka mempersepsikan harga green product cukup tinggi. Hal tersebut ditunjukkan dengan skor untuk indikator PP1 dengan pernyataan "harga produk Aqua Life 100\% Recycled lebih mahal dari air mineral lainnya" memiliki rata-rata tertinggi yakni 
sebesar 4.07. Walaupun daya beli responden masih terbatas, responden dalam penelitian ini tetap memiliki keinginan membeli produk ramah lingkungan. Hal tersebut ditandai dengan skor ratarata indikator minat beli sebesar 3,89. Tetapi, dalam penelitian ini ditemukan bahwa perceived price memiliki efek moderasi. Berdasarkan nilai koefisien determinasi pada persamaan (3) sebelum efek moderasi perceived price diketahui bahwa pengaruh green trust terhadap green purchase intention sebesar $38.7 \%$ dan setelah ada variabel moderasi dari perceived price mengalami peningkatan menjadi $49.9 \%$. Hal-hal tersebut membantu menjelaskan temuan pada penelitian ini bahwa green trust berpengaruh terhadap green purchase intention dimoderasi secara positif oleh perceived price, hal ini menunjukkan bahwa konsumen yang memiliki kepercayaan pada produk ramah lingkungan akan memiliki minat untuk membeli produk ramah lingkungan, dan hubungan tersebut dapat diperkuat oleh perceived price akan green product. Ketika harga produk ramah lingkungan lebih tinggi dari produk konvensional, kepercayaan pada produk ramah lingkungan dapat meningkat sehingga konsumen terdorong untuk membeli produk ramah lingkungan.

\section{KESIMPULAN}

Hasil penelitian dengan objek penelitian Air Minum Dalam Kemasan (AMDK) merek Aqua dengan Botol 100\% Recycled menunjukkan bahwa:

1. Green product knowledge berpengaruh positif dan signifikan terhadap green trust.

2. Green product knowledge tidak berpengaruh terhadap green purchase intention.

3. Green trust berpengaruh positif dan signifikan terhadap green purchase intention.

4. Green product knowledge berpengaruh positif dan signifikan terhadap green purchase intention dimediasi oleh green trust.

5. Green trust berpengaruh positif dan signifikan terhadap green purchase intention dimoderasi oleh perceived price.

Dari hasil penelitian ini, untuk mendorong intensi membeli konsumen pada AMDK merek Aqua dengan botol $100 \%$ recycled, pelaku bisnis perlu menumbuhkan kepercayaan konsumen akan manfaat lebih yang ditawarkan Aqua dengan kemasan barunya untuk lingkungan. Selanjutnya, untuk menumbuhkan kepercayaan tersebut pelaku usaha perlu memberikan pengetahuan yang cukup untuk dapat meyakinkan konsumen bahwa membeli AMDK merek Aqua dengan botol $100 \%$ recycle akan mampu membantu permasalahan lingkungan.

\section{DAFTAR PUSTAKA}

Akbar, W., Hassan, S., Khurshid, s., Niaz, M., \& Rizwan, M. (2014). Antecedents Affecting
Customer's Purchase Intentions towards Green Products. Journal of Sociological Research, 273-289.

Al-Gasawneh, J. A., \& Al-Adamat, A. M. (2020). The Mediating Role of e-Word of Mouth on The Relationship between Content Marketing and Green Purchase Intention. Management Science Letters, 1701-1708.

Ali, A., \& Ahmad, I. (2012). Enviroment Friendly Products: factors that influence the Green Purchase Intention of Pakisan Consumer. Pakistan Journal Engineering Technology Sciences, 84-117.

Barber, N. A., Bishop, M., \& Gruen, T. (2014). Who pays more (or less) for proenvironmental consumer goods? Using the auction method to assess actual willingnessto-pay. Journal of Environmental Psychology, 218-227.

Chen, K., \& Deng, T. (2015). Research on the Green Purchase Intentions from the Perspective of Product knowledge. Sustainability (Switzerland).

Chen, Y. L., \& Weng, C. (2015). The Influence of Environmental Friendliness on Green Trust: The Mediation Effects of Green Satisfaction and Green Perceived Quality. Sustainability, 10135-10152.

Chen, Y. S., \& Chang, C. H. (2012). Enhance Green Purchase Intentions: The Roles of Green Perceived Value, Green Perceived Risk, and Green Trust. Management Decision, 502-520.

Dimock, M. (2019). Defining generations: Where Millennials end and Generation $\mathrm{Z}$ begins. Pew Research Center, 1-7.

Fernandes, A. D., Astuti, A. B., Solimun, A. L., Nurjannah, \& Isaskar, R. (2019). Smoothing Spline Nonparametric Path: Application for Green Product and Green Marketing Strategy towards Green Product Purchasing Intention. IOP Conference Series: Earth and Environmental Science.

Ghozali, I. (2016). Aplikasi Analisis Multivariete Dengan Program IBM SPSS 23 (8th ed.). . Semarang: Badan Penerbit Universitas Diponegoro.

He, X., \& Zhan, W. (2018). How to Activate Moral Norm to Adopt Electric Vehicles in China? An Empirical Study Based on Extended Norm Activation Theory. Journal of Cleaner Production, 3546-3556.

Indrawati, D. K., \& Suparna, G. (2015). Peran Persepsi Harga dalam Memoderasi Pengaruh Pengetahuan Tentang Produk terhadap Niat Beli Produk Ramah Lingkungan Merek Toyota Agya. E-Journal Manajemen Unud, 1816-1830.

Jaiswal, D., \& Kant, R. (2018). Green Purchasing Behaviour: A Conceptual Framework and 
Empirical Investigation of Indian Consumers. Journal of Retailing and Consumer Services, 60-69.

Kanchanapibul, M., Lacka, E., Wang, X., \& Chan, H. K. (2014). An Empirical Investigation of Green Purchase Behaviour Among The Young Generation. Journal of Cleaner Production, 528-536.

Konuk, F. A., Rahman, S. U., \& Salo, J. (2015). Antecedents of Green Behavioral Intentions: A Cross-Country Study of Turkey, Finland and Pakistan. International Journal of Consumer Studies, 586-596.

Kotler, P., \& Armstrong, G. (2014). Principle of Marketing. New Jersey: Pearson Pretice Hall.

Kotler, P., \& Keller, K. L. (2016). Marketing Management. New Jersey: Pearson Pretice Hall.

Lee, Y. K. (2017). A Comparative Study of Green Purchase Intention between Korean and Chinese Consumers: The Moderating Role of Collectivism. Sustainability, 1930.

Lee, Y. K. (2020). The Relationship between green country image, green trust, and purchase intention of Korean products: Focusing on Vietnamese Gen Z consumers. Sustainability.

Leonidou, L., Coudounaris, D. N., Kvarsova, O., \& Christodoulides, P. (2015). Drivers and Outcomes of Green Tourist Attitudes and Behavior: Sociodemographic Moderating Effects. Psychology \& Marketing, 635-350.

Liao, S. H., Chung, Y. C., \& Chang, W. J. (2019). Interactivity, Engagement, Trust, Purchase intention and Word-of-Mouth: A Moderated Mediation Study. International Journal of Services, Technology and Management, 116-137.

Liobikiene, G., Mandravickaite, J., \& Bernatoniene, J. (2016). Theory of Planned Behavior Approach to Understand the Green Purchasing Behavior in the EU: A CrossCultural Study. Ecological Economics, 3846.

Newton, J. D., Tsarenko, Y., Ferraro, C., \& Sands, S. (2015). Environmental Concern and Environmental Purchase Intentions: The Mediating Role of Learning Strategy. Journal of Business Research, 1974-1981.

Nielsen. (2018). Was 2018 The Year of the Influential Sustainable Consumer? Retrieved from Nielsen: https://www.nielsen.com/us/en/insights/arti cle/2018/was-2018-the-year-of-theinfluential-sustainable-consumer/

Noor. (2017). Determinants ofGeneration Z Green Purchase Decision: A SEM-PLS Approach. International Journal of Advanced and Applied Sciences, 143-147.
Ottman, J. A. (2011). The News Rules of Green Marketing: Strategies, Tools and Inspiration For Sustainable Branding. United Kingdom: Greenleaf Publishing.

Pradnyadewi, N. P., \& Warmika, I. K. (2019). Peran Green Trust Memediasi Pengaruh Green Perceived Value Terhadap Green Purchase Intentions. E-Journal Manajemen, 27532780.

Preacher, K. J., \& Leonardelli, G. J. (2020, January 25). Calculation for the Sobel test: An interactive calculation tool for mediation tests. Retrieved from Quantpsy: http://quantpsy.org/sobel/sobel.htm

Rahim, R. A., Sulaiman, Z., Chin, T. A., Baharun, R., \& Muharam, F. M. (2016, January 25). Measuring Electronic Word of Mouth Review Adoption on Green Purchase Intention Using Source Credibility Theory. Advanced Science Letters, 4283-4287.

Rahma, E. (2019). Pertama di Indonesia, AQUA Luncurkan Botol 100\% Hasil Daur Ulang. . Retrieved from Marketeers: https://marketeers.com/pertama-diindonesia-aqua-luncurkan-botol-100-hasildaur-ulang/

Schiffman, L. G., \& Kanuk, L. L. (2015). Consumer Behavior (11th ed.). . Upper Saddle River: Pearson Prentice Hall.

sehataqua.co.id. (2020, January 25). FAQ - Aqua $100 \%$ Recycled. Retrieved from sehat aqua: https://www.sehataqua.co.id/aqualife-faq/

sehataqua.co.id. . (2020, January 25). Jelajahi Kebaikan Aqua. . Retrieved from Sehat aqua: https://www.sehataqua.co.id/jelajahkebaikan-aqua/

Sekaran, U., \& Bougie, R. (2017). Metode Penelitian Untuk Bisnis Pendekatan Pengembangan-Keahlian (6th ed.). . Jakarta: Salemba Empat.

Shen, B., Wang, Y., Lo, C. Y., \& Shum, M. (2012). The Impact of Ethical Fashion on Consumer Purchase Behavior. Journal of Fashion Marketing and Management, , 234245.

Steg, L., Perlaviciute, G., Van Der Werff, E., \& Lurvink, J. (2014). The Significance of Hedonic Values for Environmentally Relevant Attitudes, Preferences, and Actions. Environment and Behavior, 163192.

Sumarwan, U. (2015). Perilaku Konsumen: Teori dan Penerapannya dalam Pemasaran (2nd ed.). Jakarta: PT. Ghalia Indonesia.

Wang, H., Ma, B., \& Bai, R. (2018). How Does Green Product Knowledge Effectively Promote Green Purchase Intention? . Sustainability, 1-13.

Wu, X., Hu, X., Qi, W., Marinova, D., \& Shi, X. (2018). Risk knowledge, Product 
Knowledge, and Brand Benefits for Purchase Intentions: Experiences with Air Purifiers Against City Smog in China. Human and Ecological Risk Assessment: An International Journal, 7039.

WWF Indonesia. (2017). Tren Konsumsi dan Produksi Indonesia: Produsen Mampu Sediakan Produk Ekolabel dan Pasar Siap Membeli. Retrieved from WWF: https://www.wwf.or.id/?60462/Tren-

Konsumsi-dan-Produksi-Indonesia-

Produsen-Mampu-Sediakan-Produk-

Ekolabel-dan-Pasar-Siap-Membeli

Zietsman, M. L., Mostert, P., \& Svensson, G. (2018). Perceived Price and Service Quality as Mediators between Price Fairness and Perceived Value in Business Banking Relationships: A Micro-Enterprise Perspective. International Journal of Bank Marketing, 2-19. 